\title{
KETAMINE FOR DILATATION AND CURETTAGE
}

\author{
S. GALlOON, M.B., CH.B., F.F.A.R.C.S. ${ }^{*}$
}

Ketamine (Ketalar, CI-581) is a rapidly acting non-barbiturate general anaesthetic for intravenous or intra-muscular injection. It may be used as the sole anaesthetic for short procedures, as an induction agent for other anaesthetics, or as a supplement to other low potency anaesthetic agents. The advantages are claimed to be short action, minimal nausea and vomiting, wide margin of safety, maintenance of pharyngeal and laryngeal reflexes with minimal depression of respiration, and mild stimulation of the cardiovascular system. The hypertension and tachycardia resulting from the stimulation may however be a disadvantage in a patient with existing high blood pressure or cardiac decompensation. Other disadvantages are the lack of muscle relaxation, and the relatively high incidence of postoperative psychic side effects.

The pharmacological actions of ketamine in human volunteers were first reported by Domino et al. in $1965,{ }^{1}$ and in 130 patients by Corssen and Domino in $1966 .{ }^{2}$ Since then, its use in a wide variety of surgical procedures has been reported mostly encompassing clinical observations only. A few of these reports mention dilatation and curettage in passing, but there has been no concentrated study of the use of ketamine for this operation, except for the rather vague report of Dundee et al. in $1970^{3,4}$ which describes the use of ketamine for induction before continuing with nitrous oxide and oxygen. It was therefore decided to investigate the use of ketamine for this operation, which is a standard procedure with little variability in surgical technique.

\section{Method}

Ketamine was used as the sole agent for induction and maintenance of anaesthesia for the operation of dilatation and curettage of the uterus in 272 patients. In a further 50 patients the induction dose was followed by the administration of 66 per cent nitrous oxide in oxygen by face mask. There were 149 diagnostic D\&CS and 173 therapeutic abortions. All patients presenting for D\&C were included, except for patients with hypertension (systolic over $160 \mathrm{~mm} \mathrm{Hg}$, diastolic over 90 ), patients with cardiac disease, psychiatric problems or background, and patients who declined to give written consent for the administration of ketamine (only 4 altogether).

Patients were divided into 5 approximately equal groups for premedication. Two groups were given pantopon $0.286 \mathrm{mg} / \mathrm{kg}$, plus either hyoscine $0.4 \mathrm{mg}$ or atropine $0.6 \mathrm{mg}$. Two further groups were given either hyoscine $0.4 \mathrm{mg}$ or atropine $0.6 \mathrm{mg}$ alone (see Table II). The fifth group was given diazepam (Valium) $0.143 \mathrm{mg} / \mathrm{kg}$ ( $10 \mathrm{mg} / 70 \mathrm{~kg}$ ), plus hyoscine $0.4 \mathrm{mg}$. The premedication was given intramuscularly and as nearly as possible 1 1 2 hours before the start of the procedure.

*Department of Anaesthesia, University of Toronto and Toronto General Hospital. 
Anaesthesia was induced with an intravenous injection of $2.2 \mathrm{mg} / \mathrm{kg}$ of ketamine; as soon as the patient was anaesthetized she was placed in the lithotomy position. Further doses of ketamine, $0.5 \mathrm{mg} / \mathrm{kg}$ were repeated intravenously if the patient responded to the surgical stimulus or otherwise showed signs of lightening anaesthesia. The ketamine was not repeated routinely at 5- or 10-minute intervals as some reports have suggested it should be given. All the patients breathed room air throughout the procedure, except for the 50 who had supplementary nitrous oxide and oxygen. As soon as the D\&C was finished, usually in less than 30 minutes, the patient was placed in the lateral position on her bed, and moved to the Recovery Room, where she was monitored (blood pressure, pulse, respiration, etc.) and treated in the same way as any other postoperative patient.

\section{Results}

\section{A. During Anaesthesia}

\section{Clinical course}

Every patient went to sleep after the induction dose of $2.2 \mathrm{mg} / \mathrm{kg}$ and was placed in the lithotomy position $1 \frac{1 / 2}{2}$ to 2 minutes after the injection. Forty-seven patients ( 14.6 per cent) did not require more ketamine, whilst 265 required one or more supplementary doses (Table I). The therapeutic abortions required more supplementary doses because the duration of the operation was usually longer than a diagnostic D\&C. Only about half of the patients had their eyes open during the procedure (the characteristic state described), the rest had their eyes closed all the timc or went from open to closed or vice versa.

TABLE I

Number of Doses of Ketamine Required

\begin{tabular}{lrrrrrr}
\hline \hline \multirow{2}{*}{ No. of doses } & \multicolumn{2}{c}{ Diagnostic D\&C } & \multicolumn{2}{c}{ Therapeutic abortion } & & \multicolumn{2}{c}{ Total } \\
No. & Per cent & No. & Per cent & No. & Per cent \\
\hline 1 & 29 & 19.5 & 18 & 10.4 & 47 & 14.6 \\
2 & 53 & 35.6 & 44 & 25.4 & 97 & 30.1 \\
3 & 34 & 22.8 & 43 & 24.9 & 77 & 23.9 \\
4 & 26 & 17.4 & 36 & 20.8 & 62 & 19.3 \\
5 & 3 & 2.0 & 12 & 6.9 & 15 & 4.6 \\
6 or more & 4 & 2.6 & 20 & 11.6 & 24 & 7.5 \\
Total & 149 & & 173 & & 322 & 100.0 \\
\hline
\end{tabular}

Of the first 100 patients anaesthetized, 18 were classified as unsatisfactory by the anaesthetist or the gynaecologist; in the next 222 , only 3 were so classified. This was in part a matter of dosage and unfamiliarity with the agent, but 8 patients in the whole series were not relaxed enough for the preliminary examination under anaesthesia, and another 11 exhibited aimless movements of their arms and legs throughout the operation, unrelated to the surgical stimuli. The lack of adequate muscle relaxation (a known feature of ketamine) was overcome in the 8 patients by the intravenous injection of a small dose $(20-30 \mathrm{mg})$ of succinylcholine, and artificial ventilation with oxygen and a face mask for the duration of the resulting apnoea. The leg movements were completely controlled by suspending the legs 
outside the lithotomy poles instead of inside the poles, which was until then the usual habit for a D\&C.

\section{Rash}

A rash appeared on the face, neck and chest of 54 patients (17 per cent) following the first injection of ketamine. This gradually decreased and was usually gone within 15 to 20 minutes, even when the patient was still having further injections. This rash has been reported by other investigators, but does not appear to have any significance.

\section{Effect on uterus}

In the therapeutic abortions, the gynaecologists soon commented that the amount of bleeding was minimal, and that the uterus at the end of the operation was more contracted and firm than after other anaesthetics. That this was an effect of ketamine was confirmed in 16 patients by omitting the continuous intravenous infusion of Syntocin which is customarily started at the beginning of anaesthesia for therapeutic abortions; in all these 16 patients, bleeding was minimal and the uterus was firmly contracted at the end of the operation.

\section{Respiration}

In most of the patients, the respiration was monitored clinically only (frequency, movement of chest, colour) and in all except 13 patients the respiration was judged to be satisfactory. In these 13 patients it was thought necessary to support the jaw (because of obstructed breathing) or to add oxygen by face mask (because of unsatisfactory colour). In a total of 25 patients, respiration was measured by spirometry. The tracings (Figure 1) confirmed the previous clinical impression that there is a short period of complete apnoea in some patients following the injection. Eleven of the 25 patients became apnoeic for a period between one half and two minutes, with a further period of depressed tidal volume after the two minutes.

Arterial blood was drawn from the radial or brachial artery in 16 patients. The oxygen tension was above $70 \mathrm{~mm} \mathrm{Hg}$ in 13 , but 3 patients had oxygen tensions of 65,65 , and 60 in the ten-minute period after induction. All these patients were breathing room air only. In all except 3 patients, the carbon dioxide tensions were between 31-35 mm Hg., confirming the clinical observation that they tended to hyperventilate (by increasing respiratory frequency rather than volume) after the initial apnoea. The $\mathrm{pH}$ in all 16 patients was between 7.35-7.45 (Figure 2).

\section{Cardiovascular system}

In every patient in this series, both the systolic and diastolic blood pressure increased within 2 minutes of injection of ketamine, and reached maximum levels within 10 to 15 minutes (see Tables II and III). Thereafter the pressure decreased and had usually returned to the preoperative reading after a further 10 to 20 minutes, even in those patients who were having repeated injections of ketamine during this period. The increase could not be related to the preanaesthetic reading of pressure. Seventy per cent of all patients increased their systolic pressure and 81 per cent increased their diastolic pressure, by 20 per cent or more above the 


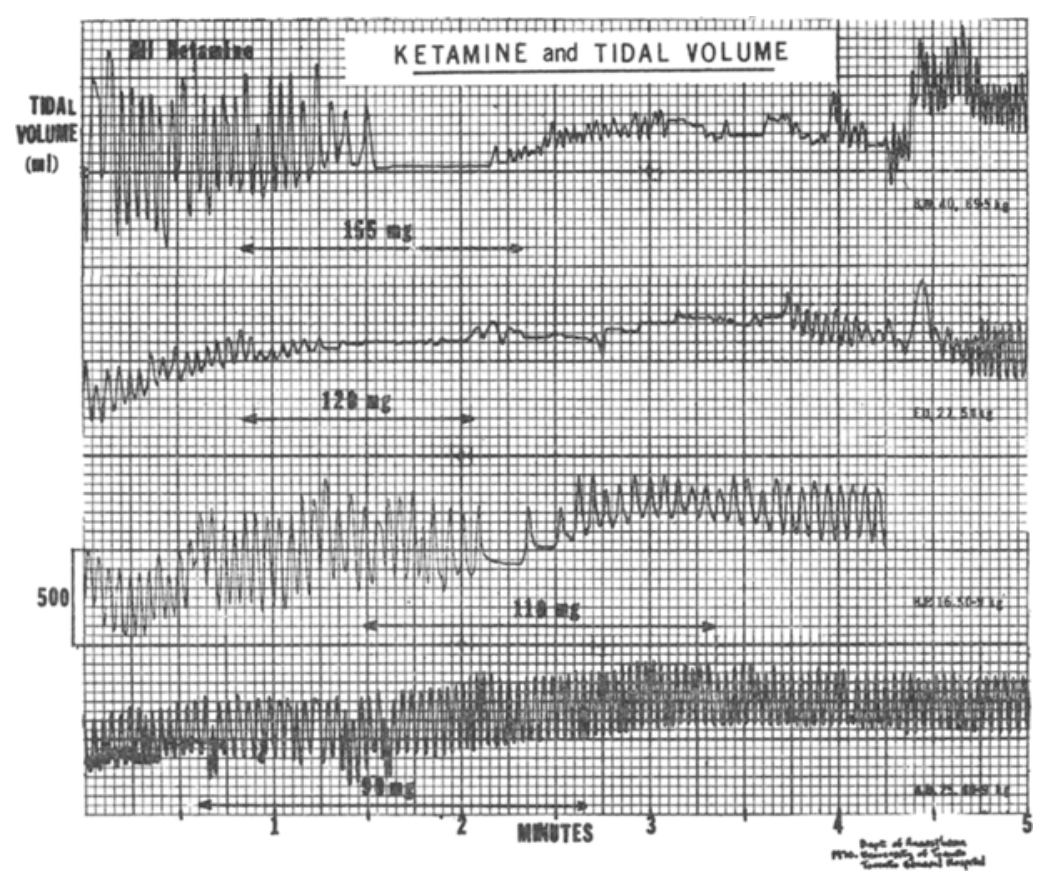

Figure 1. Spirometry tracings of tidal volume in four patients before and after ketamine.

proanaesthetic pressure. The systolic pressure rose above $160 \mathrm{~mm} \mathrm{Hg}$ in 27 per cent of all patients, and the diastolic pressure rose above $90 \mathrm{~mm} \mathrm{Hg}$ in 40 per cent of all patients.

Similarly, the pulse rate also increased in all except 15 pationts (Table IV). Seventy-three per cent of all patients increased their pulse rate 20 per cent or more above the preanaesthetic reading, and the pulse rate rose above 120 in 26.5 per cent of all patients. A source of concern in some patients was a bradycardia (below 60 ) following the initial increase in pulse rate; this occurred in 23 patients during the operation, and in a further 11 patients in the Recovery Room. In 4 of these patients the pulse rate decreased during the operation to $40,40,44$, and 45 . The bradycardia was immediately corrected by the intravenous injection of atropine 0.4 mg. All patients who developed bradycardia had been premedicated with hyoscine; no bradycardia developed in the patients premedicated with atropine. The concern is that this bradycardia might not have been recognized, had the pulse rate not been monitored so closely during the procedure.

\section{B. Postoperative}

\section{Recovery}

All patients were kept in the Recovery Room until they were wide awake, with stable blood pressure, pulse and respiration. Forty per cent of all patients opened their eyes within 15 minutes after the last dose of ketamine; 27 per cent responded 


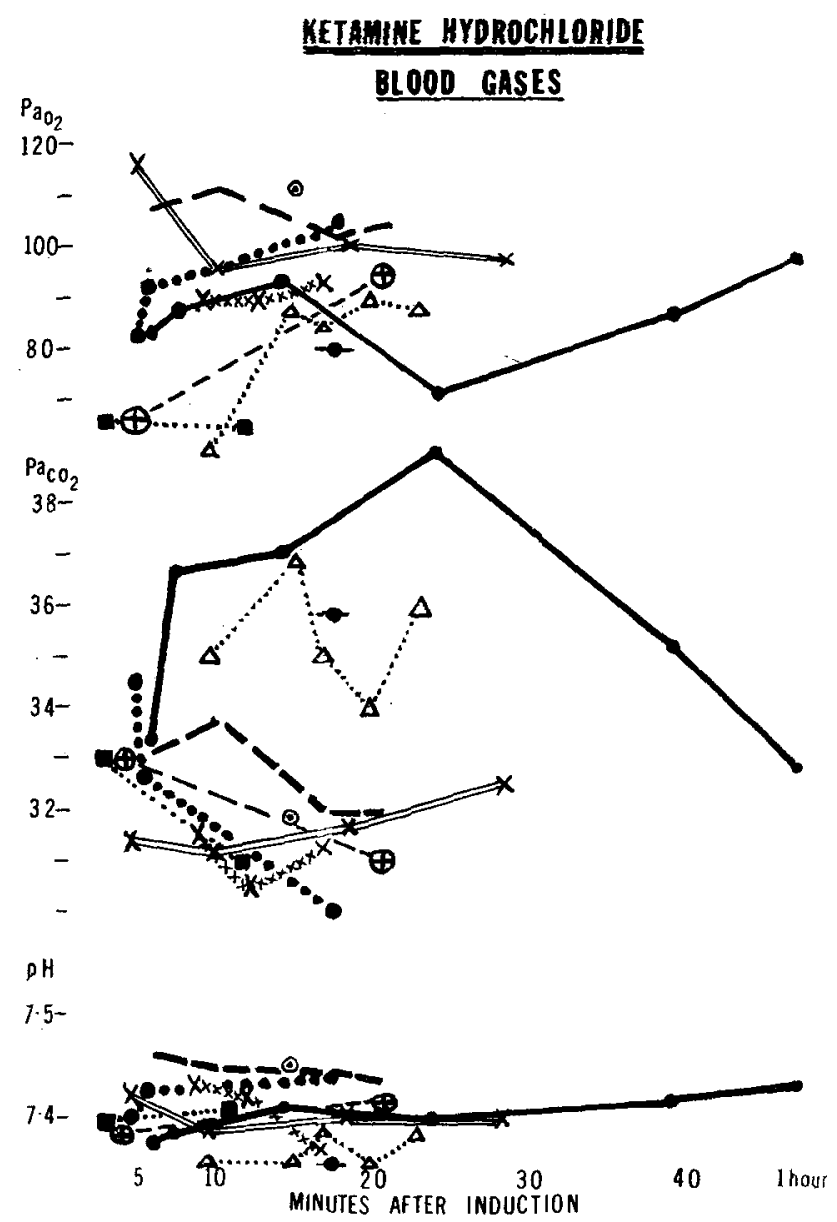

Figune 2. Arterial oxygen and carbon dioxide tensions and $\mathrm{pH}$ in patients after the administration of ketamine.

TABLE II

Changes in Systolic Blood Pressure after Ketamine, Related to Changes in PreMEdiCATION AND TO THE USE of Nitrous OXIDE as a Supplenent

\begin{tabular}{lccccccr}
\hline & $\begin{array}{c}\text { Pantopon } \\
\text { Hyoscine }\end{array}$ & $\begin{array}{c}\text { Pantopon } \\
\text { Atropine }\end{array}$ & $\begin{array}{c}\text { Hyoscine } \\
\text { alone }\end{array}$ & $\begin{array}{c}\text { Atropine } \\
\text { alone }\end{array}$ & $\begin{array}{c}\text { Diazepam } \\
\text { Hyoscine }\end{array}$ & $\begin{array}{c}\text { Pantopon } \\
\text { Atropine } \\
+N_{2} \mathrm{O}\end{array}$ & Total \\
\hline $\begin{array}{l}\text { No. of patients } \\
\text { Mean }\end{array}$ & 56 & 45 & 63 & 52 & 53 & 49 & 318 \\
Starting (mm Hg) & 118 & 119 & 115 & 117 & 114 & 120 & 117 \\
Highest (mm Hg) & 156 & 150 & 153 & 149 & 144 & 150 & 150 \\
Increase (mm Hg) & 38 & 30 & 38 & 32 & 30 & 29 & 33 \\
Increase (\%) & 33 & 26 & 33 & 27 & 27 & 25 & 29 \\
Largest increase & $104-200$ & $122-190$ & $108-180$ & $100-180$ & $108-194$ & $160-230$ & 194 \\
Highest systolic & 204 & 190 & 216 & 190 & 1940 & 230 \\
& (from 124) (from 122) (from 158) (from 130) (from 108) (from 160) \\
\hline
\end{tabular}


TABILE III

Changes in Diastolic Blood Pressure, as in Tabie II

\begin{tabular}{|c|c|c|c|c|c|c|c|}
\hline & $\begin{array}{l}\text { Pantopon } \\
\text { Hyoscine }\end{array}$ & $\begin{array}{c}\text { Pantopon } \\
\text { Atropine }\end{array}$ & $\begin{array}{l}\text { Hyoscine } \\
\text { alone }\end{array}$ & $\begin{array}{l}\text { Atropine } \\
\text { alone }\end{array}$ & $\begin{array}{l}\text { Diazepam } \\
\text { Hyoscine }\end{array}$ & $\begin{array}{l}\text { Pantopon } \\
\text { Atropine } \\
+\mathrm{N}_{2} \mathrm{O}\end{array}$ & Total \\
\hline $\begin{array}{l}\text { No. of patients } \\
\text { Mean }\end{array}$ & 56 & 45 & 63 & 52 & 53 & 49 & 318 \\
\hline $\begin{array}{l}\text { Starting } \\
\text { Highest }\end{array}$ & 69 & $\begin{array}{l}68 \\
86\end{array}$ & 63 & 68 & 62 & 66 & $\begin{array}{l}66 \\
90\end{array}$ \\
\hline Increase & $\begin{array}{l}92 \\
22\end{array}$ & $\begin{array}{l}86 \\
19\end{array}$ & $\begin{array}{l}90 \\
27\end{array}$ & $\begin{array}{l}90 \\
22\end{array}$ & $\begin{array}{l}8 \\
25\end{array}$ & $\begin{array}{l}91 \\
25\end{array}$ & $\begin{array}{l}94 \\
24\end{array}$ \\
\hline Increase $(\%)$ & 34 & 30 & 45 & 36 & 44 & 41 & 39 \\
\hline $\begin{array}{l}\text { 1. argest increase } \\
\text { highest diastolic }\end{array}$ & $\begin{array}{l}90-130 \\
130 \\
\text { (from } 90)\end{array}$ & $\begin{array}{l}78-120 \\
120 \\
\text { (from } 78 \text { ) }\end{array}$ & $\begin{array}{c}54-96 \\
110 \\
\text { (from } 68 \text { ) }\end{array}$ & $\begin{array}{l}70-120 \\
120 \\
\text { (from } 70)\end{array}$ & $\begin{array}{c}30-90 \\
112 \\
\text { (fronı } 82 \text { ) }\end{array}$ & $\begin{array}{c}55-112 \\
150 \\
\text { (from } 80) \text { ) }\end{array}$ & \\
\hline
\end{tabular}

TABLE IV

Changes in Pulse Rate, as in Table 11

\begin{tabular}{|c|c|c|c|c|c|c|c|}
\hline & $\begin{array}{l}\text { Pantopon } \\
\text { Hyoscine }\end{array}$ & $\begin{array}{l}\text { Pantopon } \\
\text { Atropine }\end{array}$ & $\begin{array}{l}\text { Hyoscine } \\
\text { alone }\end{array}$ & $\begin{array}{l}\text { Atropine } \\
\text { alone }\end{array}$ & $\begin{array}{l}\text { Diazepan } \\
\text { Hyoscine }\end{array}$ & $\begin{array}{l}\text { Pantopon } \\
\text { Atropine } \\
+\mathrm{N}_{2} \mathrm{O}\end{array}$ & Total \\
\hline $\begin{array}{l}\text { No of patients } \\
\text { Mean }\end{array}$ & 56 & 45 & 63 & 52 & 53 & 49 & 318 \\
\hline $\begin{array}{l}\text { Starting } \\
\text { Highest }\end{array}$ & $\begin{array}{r}74 \\
106\end{array}$ & $\begin{array}{r}89 \\
122\end{array}$ & $\begin{array}{r}74 \\
101\end{array}$ & $\begin{array}{r}89 \\
125\end{array}$ & $\begin{array}{r}79 \\
109\end{array}$ & $\begin{array}{r}90 \\
104\end{array}$ & $\begin{array}{r}82 \\
108\end{array}$ \\
\hline Increase & 32 & 32 & 27 & 36 & 30 & 13 & 28 \\
\hline Increase $(\%)$ & 45 & 40 & 39 & 42 & 40 & 17 & 37 \\
\hline $\begin{array}{l}\text { Largest increase } \\
\text { lighest pulse }\end{array}$ & $\begin{array}{l}66-160 \\
160 \\
\text { (from 66) }\end{array}$ & $\begin{array}{l}66-144 \\
172 \\
\text { (from 108) }\end{array}$ & $\begin{array}{l}60-156 \\
156 \\
\text { (from 60) }\end{array}$ & $\begin{array}{l}72-144 \\
168 \\
\text { (from } 96)\end{array}$ & $\begin{array}{l}54-102 \\
156 \\
\text { (from 88) }\end{array}$ & $\begin{array}{l}66-116 \\
132 \\
\text { (from 108) }\end{array}$ & \\
\hline
\end{tabular}

to a command within 15 minutes, 70 per cent within 30 minutes (Figure 3 ). Most patients left the Recovery Room within one to one and one-half hours after the last dose. However, 75 patients (24.2 per cent), having opened their eyes and responded to a command, were found to be (or complained later of being) drowsy for a period of four or five hours after the operation, even though they could be wakened and were perfectly rational when this was done. There was really no difference in recovery times following different premedications, except for a slight, non-significant decrease in these times in patients who had hyoscine or atropine beforehand and longer recovery times in patients who had nitrous oxide as a supplement.

\section{Headache and dizziness}

Fifteen patients complained of headache and dizziness for some hours after they woke up, a further 40 of headache alone, and 37 of feeling dizzy without headache for some time after the operation. The total incidence of headache and/or dizziness was therefore 29.7 per cent of all patients, i.e., approximately 1 in every 3 patients. 


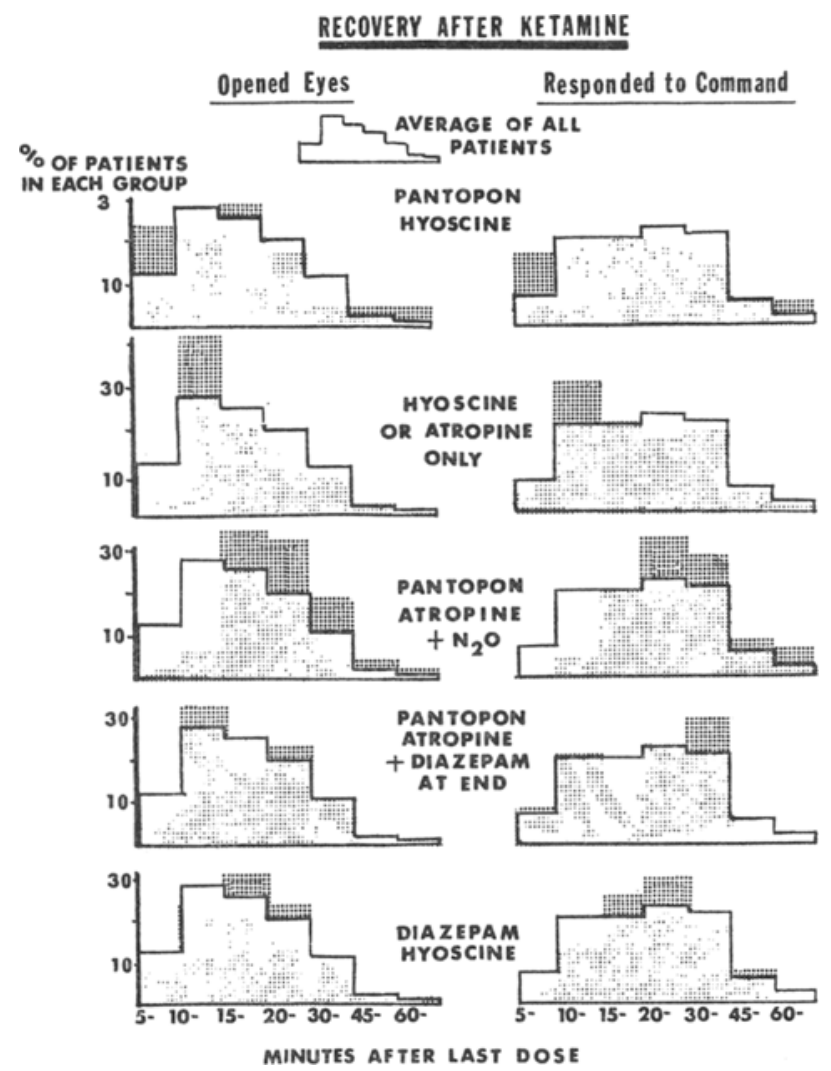

Figure 3. Recovery times following ketamine. The time has been measured from the administration of the last dose of ketamine. The effect of different premedications, nitrous oxide as a supplement, and diazepam injected at the end of the operation is shown. The average time for all patients in the series has been superimposed on the time for each of the five groups.

\section{Nausea and Vomiting}

Thirty patients ( 9.6 per cent) were nauseous only, another 100 (32 per cent) vomited, and 183 ( 58.5 per cent) felt neither nauseous nor vomited (Table V). There was a considerable difference in the incidence of nausea and vomiting depending on the premedication. Of those who had pantopon and hyoscine as premedication, only half ( 49 per cent) were neither nauseous nor vomited, whilst of those who had hyoscine alone as premedication, 90 per cent were neither nauseous nor vomited. On the other hand, only 28 per cent of those patients who had supplementary nitrous oxide throughout the procedure were neither nauseous nor vomited (Table V). Table VI shows that the incidence of nausea and vomiting was the same whether the patient had a diagnostic D\&C or a therapeutic abortion.

\section{Postoperative Dreams}

One of the major disadvantages of ketamine seems to be the occurrence of dreams or hallucinations in the immediate postoperative period. Some of these are frankly 
'ABIS $V$

Incubane of Postoplikatrve Nausea and Vomiting, Related to Changes in Premedication

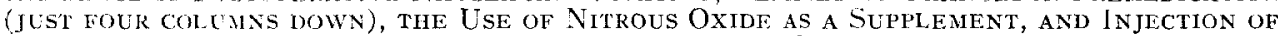
DIAZEPAM AT THE END OF THE OPERATION

\begin{tabular}{|c|c|c|c|c|c|c|c|}
\hline & \multicolumn{2}{|c|}{ Nausea only } & \multicolumn{2}{|c|}{ Vomiting } & \multicolumn{2}{|c|}{ Neither } & \multirow[b]{2}{*}{ Total } \\
\hline & No. & Per cent & No. & Per cent & No. & Percent & \\
\hline Pantopon + lyoscine & 11 & 20.0 & 17 & 30.9 & 27 & 49.1 & 55 \\
\hline Hyoscine & 1 & 1.8 & 5 & 9.1 & 49 & 89.1 & 55 \\
\hline Atropine & 5 & 10.0 & 16 & 32.0 & 29 & 58.0 & 50 \\
\hline Biazepam + Hyoscine & 3 & 5.8 & 6 & 11.5 & 43 & 82.7 & 52 \\
\hline Pantopon + Atropine & & & & & & & \\
\hline $\begin{array}{l}+\mathrm{N}_{2} \mathrm{O} \text { supplement } \\
\text { Pantopon }+ \text { Atropine }\end{array}$ & 4 & 8.0 & 32 & 64.0 & 14 & 28.0 & 50 \\
\hline+ Diazepam at end & 6 & 11.8 & 24 & 47.1 & 21 & 41.1 & 51 \\
\hline Total & 30 & 9.6 & 100 & 31.9 & 183 & 58.5 & 313 \\
\hline
\end{tabular}

TABLE VI

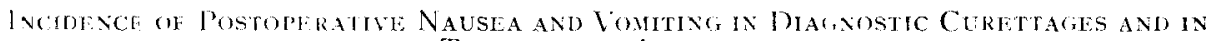
THEkAPETTC ABORTIONS

\begin{tabular}{|c|c|c|c|c|c|c|c|c|}
\hline & \multicolumn{2}{|c|}{ Natusea only } & \multicolumn{2}{|c|}{ Vomiting } & \multicolumn{2}{|c|}{ Neither } & \multicolumn{2}{|c|}{ Total } \\
\hline & No. & Per cent & No. & Per cent & No. & Per cent & No. & Per cent \\
\hline Diagnostic n\&C & 18 & 12.9 & 38 & 27.3 & 83 & 59.7 & 139 & 44.4 \\
\hline Therapeutic abortion & 12 & 6.9 & 62 & 35.6 & 100 & 57.5 & 174 & 55.6 \\
\hline Toral & 30 & 9.6 & 100 & 31.9 & 183 & 58.5 & 313 & 100 \\
\hline
\end{tabular}

unpleasant to the patient. All patients were questioned about these experiences within 24 hours of the operation, and divided into those who had dreams and those who had none. The dreams were classified as pleasant or unpleasant, mostly on the patient's opinion. Table VII shows that the overall incidence of postoperative dreams is very nearly 50 per cent, with one in every six patients ( 16.3 per cent) experiencing an unpleasant dream. There is a considerable difference in the incidence of dreams following the different premedications and procedures. The rather high incidence of nausea and vomiting, slightly long recovery, and dreams in 1 of cvery 3 of the first 50 patients (who were all premedicated with pantopon and hyoscine), prompted the omission of the pantopon in the next 50 . Unfortunately, although the incidence of nausea and vomiting was dramatically reduced and the recovery slightly shortened by the use of hyoscine alone, the incidence of dreams was increased from 33 per cent to 49 per cent, although, in fact, most of the increase was in the "pleasant" category. The next group of 50 patients was accordingly premedicated with atropine alone, on the supposition that hyoscine itself might be a hallucinogenic drug, but the dreams occurred even more frequently and 1 in every 3 patients in this group had an unpleasant dream (Table VII).

The next group was premedicated with pantopon and atropine (because atropine seemed to produce rather fewer troubles with the cardiovascular system) and the patients were given an intravenous injection of diazepam $2.5 \mathrm{mg}$ just before leaving the operating room, after the operation. The incidence of dreams was less than with 
TABLE VII

Incidence of Postoperative Dreams, Related as in Table V

\begin{tabular}{|c|c|c|c|c|c|c|c|c|}
\hline & \multirow[b]{2}{*}{$\begin{array}{l}\text { No. of } \\
\text { patients }\end{array}$} & \multicolumn{2}{|c|}{ Pleasant } & \multicolumn{3}{|c|}{ Unpleasant } & \multicolumn{2}{|c|}{ None } \\
\hline & & No. & $\begin{array}{l}\text { Per cent } \\
\text { of all } \\
\text { patients }\end{array}$ & No. & $\begin{array}{c}\text { Per cent } \\
\text { of all } \\
\text { patients }\end{array}$ & $\begin{array}{l}\text { Per cent } \\
\text { of all } \\
\text { dreams }\end{array}$ & No. & $\begin{array}{l}\text { Per cent } \\
\text { of all } \\
\text { patients }\end{array}$ \\
\hline Pantopon + Hyocsine & 55 & 11 & 20.0 & 7 & 12.7 & 38.9 & 37 & 67.3 \\
\hline Hyose & 55 & 19 & 35.5 & 8 & 14 & & 8 & 50.9 \\
\hline Atropine & 5 & 21 & 42.0 & 14 & 28.0 & 40.0 & 15 & 30.0 \\
\hline Diazepam + Hyoscine & 52 & 10 & 19.2 & 3 & 5.8 & 23.1 & 39 & 75.0 \\
\hline $\begin{array}{c}\text { Pantopon + Atropine } \\
+\mathrm{N}_{2} \mathrm{O} \text { supplement }\end{array}$ & 50 & 10 & 20.0 & 11 & 22.0 & 52.4 & 29 & 58.0 \\
\hline $\begin{array}{l}\text { Pantopon + Atropine } \\
+ \text { Diazepam at end }\end{array}$ & 51 & 20 & 39.2 & 8 & 15.7 & 28.6 & 23 & 45.1 \\
\hline Total & 313 & 91 & 29.1 & 51 & 16.3 & 35.9 & 171 & 54.6 \\
\hline
\end{tabular}

TABLE VIII

Incidence of Postoperative Dreams in Diagnostic Curettages and in Therapeutic ABORTIONS

\begin{tabular}{|c|c|c|c|c|c|c|c|}
\hline & \multicolumn{2}{|c|}{ Pleasant } & \multicolumn{2}{|c|}{ Unpleasant } & \multicolumn{2}{|c|}{ None } & \multirow[b]{2}{*}{ Total } \\
\hline & No. & Per cent & No. & Per cent & No. & Per cent & \\
\hline $\begin{array}{l}\text { Diagnostic D\&C } \\
\text { Therapeutic abortion }\end{array}$ & $\begin{array}{l}39 \\
52\end{array}$ & $\begin{array}{l}28.1 \\
29.9\end{array}$ & $\begin{array}{l}23 \\
28\end{array}$ & $\begin{array}{l}16.5 \\
16.1\end{array}$ & $\begin{array}{l}77 \\
94\end{array}$ & $\begin{array}{l}55.4 \\
54.0\end{array}$ & $\begin{array}{l}139 \\
174\end{array}$ \\
\hline Total & 91 & 29.0 & 51 & 16.3 & 171 & 54.7 & 313 \\
\hline
\end{tabular}

atropine, but still higher than the incidence in the first group premedicated with pantopon and hyoscine. The next group was again premedicated with pantopon and atropine but the induction dose of ketamine was followed immediately by 66 per cent nitrous oxide in oxygen by face mask, in an attempt to reduce the number of doses of ketamine, since it has been suggested that the incidence of dreams is related to the number of doses. The incidence of dreams was closer to the first group of patients who were premedicated with pantopon and hyoscine, but the incidence of unpleasant dreams particularly was considerably increased in the nitrous oxide/oxygen group. The final group was premedicated with diazepam, $0.143 \mathrm{mg} / \mathrm{kg}$ plus hyoscine $0.4 \mathrm{mg}$ intramuscularly and Table VII shows that the incidence of dreams was reduced to 25 per cent, with only 3 patients of the total of 51 having unpleasant dreams. Also in this group, 82 per cent of all the patients were neither nauseous nor vomited postoperatively.

Table VIII shows that the incidence of pleasant and unpleasant dreams is the same in patients having diagnostic curettage and those having therapeutic abortions. This refutes the suggestion that, because the latter group are more emotionally disturbed when they come in for operation, they are more likely to have dreams.

\section{Other Disturbances}

Forty-two patients ( 13 per cent) behaved irrationally in the Recovery Room before they wakened completely, and by their behaviour caused some concern 
TABLE IX

Incinence of Disturbances in the Recovery Room, Related to the Incidence of PostOPERATIVE DREAMS

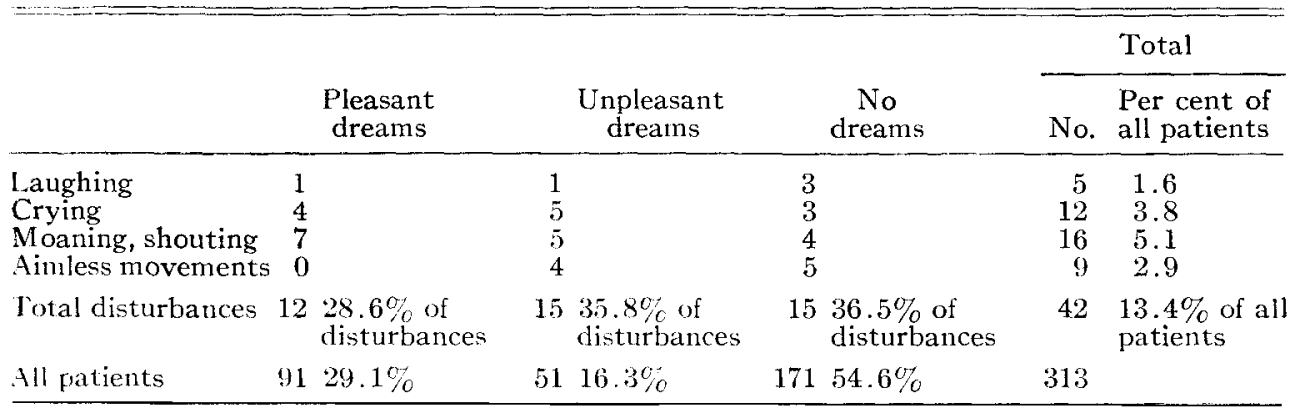

TABL.E $\mathrm{X}$

Pustoperative Dreams, Comparing the Incidence after all Ketamine Patuents, Diazepam Premedication and Ketamine, and other General Anaesthetics

\begin{tabular}{|c|c|c|c|c|c|c|c|}
\hline & \multicolumn{2}{|c|}{$\begin{array}{l}\text { Pleasant } \\
\text { dreams }\end{array}$} & \multicolumn{2}{|c|}{$\begin{array}{l}\text { Unpleasant } \\
\text { dreams }\end{array}$} & \multicolumn{2}{|r|}{ None } & \multirow{2}{*}{$\begin{array}{c}\text { Total } \\
\text { patients }\end{array}$} \\
\hline & No. & Per cent & No. & Per cent & No. & Per cent & \\
\hline Ketamine all patients & 91 & 29.1 & 51 & 16.3 & 171 & 54.6 & 313 \\
\hline $\begin{array}{l}\text { Ketamine diazepam } \\
\text { premedication } \\
\text { other anaesthetics }\end{array}$ & $\begin{array}{l}10 \\
20\end{array}$ & $\begin{array}{l}19.2 \\
19.0\end{array}$ & $\begin{array}{l}3 \\
9\end{array}$ & $\begin{array}{l}5.8 \\
8.6\end{array}$ & $\begin{array}{l}39 \\
76\end{array}$ & $\begin{array}{l}75.6 \\
72.4\end{array}$ & $\begin{array}{r}52 \\
105\end{array}$ \\
\hline
\end{tabular}

TABLE XI

Pogtoperative Nalsfa and Vomiting, Comparing the Incidence After All Ketamine Patifats, Diazepan Premedication and Ketamine, and Other General anaesthetic AGENTS

\begin{tabular}{|c|c|c|c|c|c|c|}
\hline & \multicolumn{2}{|c|}{ Nausea } & \multicolumn{2}{|c|}{ Vomiting } & \multicolumn{2}{|c|}{ Neither } \\
\hline & No. & Per cent & No. & Per cent & No. & Per cent \\
\hline Ketamine all patients & 30 & 9.6 & 100 & 31.9 & 183 & 58.5 \\
\hline Ketamine diazepam premedication & 3 & 5.8 & 6 & 11.5 & 43 & 82.7 \\
\hline Other anaesthetics & 15 & 14.3 & 29 & 27.6 & 61 & 58.1 \\
\hline
\end{tabular}

among the nursing staff. These disturbances were described as senseless laughing or crying, moaning and shouting, and aimless movements of the arms and legs. There appears to be some relationship between these disturbances and the occurrence of dreams (Table IX). Although some patients who had these disturbances in the Recovery Room later reported no dreaming, it can be seen that 3 of every 5 patients showing these disturbances did have dreams, and 1 of every 3 had an unpleasant dream.

\section{Dreams with other Anaesthetics}

Concurrent with the study of ketamine and postoperative dreams, 105 patients who had other anaesthetics (mostly thiopentone followed by nitrous oxide and 
halothane or methoxyflurane) for D\&C or therapeutic abortion, were questioned about dreams and postoperative nausea and vomiting. Twenty-nine patients $(27.6$ per cent) had dreams postoperatively and 9 of these ( 8.6 per cent of the total patients) were described by the patients as unpleasant (Table X). Sixty-one patients (58.1 per cent) were neither nauseous nor vomited, 15 (14.3 per cent) were nauseous only, and 29 (27.6 per cent) vomited (Table XI).

\section{Discussion}

The results of this study of 322 patients anaesthetized with ketamine for the operation of $\mathrm{D} \& \mathrm{C}$ are presented above. It would seem that ketamine is a satisfactory anaesthetic for dilatation and curettage, and is particularly suitable for therapeutic abortions, because of the minimal bleeding and the firm and contracted uterus produced even without an intravenous infusion of Syntocin.

The increase in blood pressure and pulse rate presented no problems in the patients studied, because in general they were young and healthy, but ketamine should not be administered to a patient with hypertension or congestive heart failure. The bradycardia produced in a small number of patients could be dangerous, particularly if it is not immediately recognized. This however is probably a result of the dilatation of the cervix, rather than a ketamine effect, because it has not been reported in other studies with ketamine. It can be avoided by the use of atropine instead of hyoscine in the premedication and if it does occur, it can easily be corrected by the intravenous injection of atropine.

Although the incidence of respiratory complications (cyanosis, obstruction of the airway) was very low, it stresses the need for the vital signs to be monitored continuously after administration of ketamine, as with any other anaesthetic. It also confirms the statement made by some of the other investigators of ketamine, that it should only be administered by a doctor who has been trained to recognize and treat these complications.

Acceptance of ketamine by anaesthetists would seem to be more dependent on its postoperative effects than on its anaesthetic properties, in particular the incidence of nausea and vomiting, and postoperative dreams and hallucinations. The standard conditions maintained throughout the study reported here, point to the fact that postoperative nausea and vomiting can vary from 72 per cent of patients to 10 per cent of patients depending on the premedication. The highest incidence of vomiting was in those patients who were premedicated with pantopon and atropine, and the lowest incidence was in those who had hyoscine alone.

The main concern in the use of ketamine in adults is the incidence of postoperative emergence phenomena, including dreams and hallucinations. Parke-Davis and Co., in a comprehensive report on the use of ketamine in over 12,000 patients by various investigators, ${ }^{5}$ give an overall incidence of 11.7 per cent of patients who dreamed; 5.9 per cent were graded as unpleasant. Their figures also show that these disturbances are higher in the female, in fact two-thirds of the dreams were in females. Dundee et al. ${ }^{3,4}$ in their report of the use of ketamine in minor and major gynaecological procedures, found that one-third of all patients were disturbed to some extent when regaining consciousness and, in half of these, the upset was 
severe. They also showed that some of the premedicant drugs could reduce the undesirable effects of ketamine, but they varied the dose of ketamine and it is not clear whether their figures with the different premedicants were all D\&CS.

There is no doubt that patients do dream during or after anaesthesia, and Brice et $a .^{6}$ reported, in patients anaesthetized with thiopentone, curare, nitrous oxide and oxygen alone, an incidence of dreams of 25 out of 57 patients ( 43.8 per cent). Three of these ( 5 per cent) were unpleasant. In a further study of 120 patients, Harris et al. ${ }^{7}$ reported dreams in 57 per cent of patients anaesthetized with nitrous oxide and oxygen alone, and 23 per cent in patients supplemented with 0.1 per cent0.3 per cent methoxyflurane. There were no dreams in those patients supplemented with 0.3 per cent-0.5 per cent halothane. Wilson and Turner ${ }^{8}$ found an incidence of 30 per cent of patients who recalled some form of dream sequence, with half of these unpleasant, while Crawford ${ }^{9}$ found an incidence of 6.5 per cent of dreams, with two-thirds of these unpleasant. Both these reports concerned patients anaesthetized for caesarean section, some with maintenance with nitrous oxide and oxygen only, others with methoxyflurane added. The concurrent study reported here (Table $\mathrm{X}$ ) on patients anaesthetized for $\mathrm{D} \& \mathrm{C}$ and therapeutic abortion with anaresthetics other than ketamine, shows that 27.6 per cent had dreams.

The overall incidence of dreams following ketamine in this study was 45 per cent, but there is a marked difference in the incidence with different premedications. The use of atropine alone produced the highest incidence of dreaming, 70 per cent of all patients having dreams, 40 per cent of these being unpleasant; on the other hand the use of diazepam and hyoscine as premedication produced an incidence of only 25 per cent of dreams, of which only 1 in 5 was unpleasant. This compares very favourably with the concurrent study of dreams following the use of other anaesthetics for the same operation, where the incidence of dreams was 27 per cent (Table $\mathrm{X}$ ). The use of diazepam and hyoscine also reduced the nausea and vomiting following the anaesthetic to 17 per cent, which is almost as good as the incidence with hyoscine alone.

It has been suggested that the dreams can be considerably reduced by putting the patient in a quiet darkened room and not disturbing her at all until she wakes up. This study may be criticized for not doing so, but it would be impossible in our Recovery Room, and, I am sure, in many others. We also believe that it is most important to monitor closely blood pressure, pulse, respiration and state of consciousness during this period, and this is borne out by the 11 patients mentioned earlier who developed bradycardia in the Recovery Room. It would be a major disadvantage of any new anaesthetic agent if our whole concept and procedure of immediate postoperative care had to be drastically changed in order to prevent a complication.

\section{SUMMARY}

Ketamine has been used satisfactorily for the operation of uterine curettage (D\&C) and therapeutic abortion, as the sole anaesthetic agent in 272 patients and followed by nitrous oxide and oxygen in a further 50 . It is particularly suitable for a therapeutic abortion because of the contraction of the uterus and minimal bleeding. Complications during anaesthesia were few, but their detection does require 
careful monitoring and treatment by experienced doctors, as with any other general anaesthesia. Postoperative recovery times (to a small extent) and nausea and vomiting and dreams (to a considerable extent) were affected by variations in the premedication. The best premedication would appear to be diazepam (Valium) $0.143 \mathrm{mg} / \mathrm{kg}$, plus hyoscine $0.4 \mathrm{mg}$ or atropine $0.6 \mathrm{mg}$. Eighty-two per cent of patients in this group were neither nauseous nor vomited postoperatively, and the incidence of dreams was 25 per cent, comparable to an incidence of 27 per cent of dreams found in a concurrent study of patients anaesthetized with other anaesthetics for the same operation.

\section{RÉSUMÉ}

Pour l'opération de curettage uterin ou d'avortement thérapeutique, on a utilisé avec satisfaction la kétamine comme seul agent anesthésique chez 272 malades et on l'a fait compléter par du protoxyde d'azote-oxygène chez 50 autres. Cet anesthésique convient particulièrement aux cas d'avortement thérapeutique à cause des contractions utérines et du saignement minime. Durant l'anesthésie, les complications ont été rares, mais comme dans toute anesthésie générale, une détection rapide et un traitement efficace sont requis. La durée du réveil (peu influencée) et les nausées, vomissements et cauchemars (assez importants) one été influencés par la prémédication. La meilleure prémédication semble être le diazépam (valium) $0.143 \mathrm{mg} / \mathrm{kg}$, plus l'hyoscine $0.4 \mathrm{mg}$ ou l'atropine $0.6 \mathrm{mg}$. Quatre-vingt-deux pour cent des malades de ce groupe n'ont eu ni nausées ni vomissements post-opératoires, et la fréquence des cauchemars a été de 25 pour cent comparés à 27 pour cent chez les malades ayant reçu d'autres anesthésiques pour la même opération.

\section{ACKNOWLEDGEMENTS}

I would like to thank Dr R. A. Gordon, Chairman of the Department of Anaesthesia of the University of Toronto, for his continual support and help throughout the study. I am indebted to all the gynaecologists of the Toronto General Hospital for their patience and tolerance and to Mrs Corrigan and her Recovery Room staff for their careful observation of the patients in the immediate postoperative period. My thanks to the anaesthesia residents who helped with many of the cases, and also to my colleagues, Dr B. M. Marshall and Dr J. Desmond for help and criticism in finalizing the manuscript. Finally, thanks to Parke-Davis and Company, Ltd, for generous supplies of Ketamine.

\section{REFERENCES}

1. Domino, E. F.; Chodoff, P.; \& Conssen, G. Pharmacologic Effects of Cl-581, A New Dissociative Anaesthetic, in Man. Clin. Pharmacol. \& Therap., 6: 279 (1965).

2. Corssen, G. \& Domino, E. F. Dissociative Anesthesia: Further Pharmacologic Studies and First Clinical Experience with the Phencyclidine Derivative Cl-581. Anesth. \& Analg., 45: 29 (1966).

3. Dundee, J. W.; Knox, J. W. D.; Black, G. W.; Moore, J.; Pandit, S. K.; Bovill, J.; Clarke, R. S. J.; Love, S. H. S.; ElliotT, J.; \& Copper, D. L. Ketamine as an Induction Agent in Anaesthetics. Lancet, $1: 1370$ (1970).

4. Knox, J. W. D.; Bovirl, J. G.; Clarke, R. S. J.; \& Dundee, J. W. Clinical Studies of Induction Agents: xxxvi: Ketamine. Brit. J. Anaesth., 42: 875 (1970). 
5. Parke-Davis. Ketalar Cl-581. A Short-acting Anesthetic. Medical Summary. June 18th, 1970.

6. Brice, D. D.; Hetherington, R. R. \& Uttinc, J. E. A Simple Study of Awareness and Dreaming During Anaesthesia. Brit. J. Anaesth., 42: 535 (1970).

7. Harris, T. J. B.; Brice, D. D.; Hetherington, R. R.; \& Utting, J. E. Dreaming Associated with Anaesthesia: The Influence of Morphine Premedication and Two Volatile Adjuvants. Brit. J. Anaesth., 43: 172 (1971).

8. Wirson, J. \& Turner, D. J. Awareness During Caesarean Section under General Anaesthesia. Brit. Med. J., 1: 280 (1969).

9. Crawford, J. Selwyn. Awareness During Operative Obstetrics under General Anaesthesia. Brit. J. Anaesth., 43: 179 (1971). 